\title{
A new species of Mazosia (lichenised Ascomycetes: Roccellaceae) from Tasmania
}

\author{
Gintaras Kantvilas*
}

\section{Article info}

Received: 16 Jul. 2020

Revision received: 14 Aug. 2020

Accepted: 15 Aug. 2020

Published: 29 Dec. 2020

\section{Associate Editor}

María de los Angeles Herrera

Campos

\begin{abstract}
Two species of Mazosia occur in Tasmania: the foliicolous, pantropical M. phyllosema and $M$. corticola, here described as new to science. The new species is characterised by a corticolous thallus containing psoromic acid and three-septate ascospores, 17-27 $\times$ 4-6.5 $\mu \mathrm{m}$; it occurs in Tasmanian and Victoria.
\end{abstract}

Key words: Australia, corticolous, foliicolous, lichens, new species

\section{Introduction}

The genus Mazosia was introduced by Massalongo (1854), but was not generally taken up until the monumental work of Santesson (1952), who also discussed the confusion surrounding the application of this name and its taxonomic affinities. Following the work of Kalb \& Vězda (1988), Lücking \& Matzer (1996) and others, the genus is now included without controversy in the Roccellaceae with Enterographa, a likely close relative (Sparrius 2004), and positioned in a lineage that also includes Dichosporidium, Enterographa and Erythrodecton (Ertz et al. 2015). Mazosia is a typical element of tropical rainforests (Lücking 2008) and of the nine species reported for Australia (McCarthy 2020), only one, the subcosmopolitan M. phyllosema, extends into temperate latitudes (McCarthy et al. 2001). Of the more than 25 described species, the majority are foliicolous. Only six corticolous species are known, four confined to the Neotropics (Aptroot et al. 2014) and two to Japan (Sakata et al. 2017). Thus, the discovery of a corticolous species in the Nothofagus-dominated cool temperate rainforests of Tasmania can be considered truly remarkable. This species is described here as new to science.

\section{Material and methods}

The study is based chiefly on the collections of the author from mainland Australia and Tasmania, housed in the Tasmanian Herbarium (HO), and comparisons with reference exsiccata from other regions. Anatomical observations

Tasmanian Herbarium, Tasmanian Museum and Art Gallery, Box 5058, UTAS LPO, Sandy Bay, Tasmania 7005, Australia

* Corresponding author e-mail: Gintaras.Kantvilas@tmag.tas.gov.au and measurements are based on thin, hand-cut sections of the thallus, apothecia and pycnidia, mounted in water, $10 \% \mathrm{KOH}(\mathrm{K})$, Lugol's iodine (I), ammoniacal erythrosin and/or lactophenol cotton blue. Application of Lugol's iodine after pre-treatment with $\mathrm{KOH}$ is abbreviated as $\mathrm{KI}$. Ascospore measurements are presented in the format $5^{\text {th }}$ percentile - average $-95^{\text {th }}$ percentile with outlying values in brackets and $n$ signifying the number of observations. Chemical analyses were undertaken by thin-layer chromatography (TLC) using standard methods (Orange et al. 2010). Solvent A was the preferred routine medium. The presence of psoromic acid was further confirmed by Prof. J.A. Elix, Canberra using high-performance liquid chromatography (Elix et al. 2003).

\section{Taxonomy}

Mazosia corticola Kantvilas, sp. nov.

(Figs 1-2)

MycoBank MB 836454

Diagnosis: A speciebus omnibus corticolas Mazosiae acidum psoromicum continenti et ascosporis 17-27 $\mu \mathrm{m}$ longis, 4-6.5 $\mu \mathrm{m}$ latis differt.

Type: Australia, Tasmania, Ben Ridge Road, $850 \mathrm{~m}$ alt., on Atherosperma moschatum in rainforest, 10 December 1981, G. Kantvilas 1108/81 (HO - holotype; BM - isotype).

Description. Thallus crustose, smooth or faintly rimose, pale beige-brown to grey-brown or grey, ecorticate, 30-60 $\mu \mathrm{m}$ thick, forming small continuous patches to $25 \mathrm{~mm}$ wide that coalesce when adjacent, each delimited by an effuse, black prothallus; photobiont trentepohlioid, with cells subglobose to ellipsoid, 8-17 × 7-17 $\mu \mathrm{m}$, occurring singly or in short chains. Apothecia zeorine, 
$0.2-0.5 \mathrm{~mm}$ wide, roundish or irregularly ellipsoid, sunken in the thallus surface or broadly adnate; disc plane, grey-brown to blackish, epruinose; thalline margin whitish, ragged or scabrid, $30-80 \mu \mathrm{m}$ thick; proper exciple persistent, visible as a thin, black, glossy rim surrounding the disc, in section pale red-brown, $\mathrm{K}+$ olive-green, 20-50 $\mu \mathrm{m}$ thick, composed of \pm vertically orientated hyphae 3-6 $\mu \mathrm{m}$ thick, usually surrounded in the basal part by a band of hyaline, rhomboid crystals $5-10 \mu \mathrm{m}$ wide and insoluble in $\mathrm{K}$. Hypothecium pale brown, weakly $\mathrm{K}+$ greenish grey, 20-50 $\mu \mathrm{m}$ thick, not inspersed. Hymenium (60-)70-90(-100) $\mu \mathrm{m}$ thick, hyaline, hemiamyloid, I+ yellow-brown, KI+ faintly bluish; paraphyses $1.5-2 \mu \mathrm{m}$ thick, branched and anastomosing, extending well above the level of the asci, with apices neither swollen nor pigmented; asci 8 -spored, cylindrical to narrowly clavate, 55-70 $(-75) \times 11-15 \mu \mathrm{m}$, approximating the vulgata-type (Torrente \& Egea 1989), with a weakly KI+ blue outer sheath and a well-developed, very weakly KI+ blue tholus with a highly reduced, faintly amyloid ring and a blunt, short ocular chamber. Ascospores fusiform, 3-septate, $(17-) 18.5-22.1-25(-27) \times 4-4.9-5.5(-6.5) \mu \mathrm{m}(\mathrm{n}=50)$, with blunt apices; locules \pm cylindrical or roundish, with the uppermost median cell usually slightly but distinctly swollen; wall $\sim 0.5 \mu \mathrm{m}$ thick. Pycnidia immersed, black, minute; conidia (macroconidia) oblong, 5-6.5 × 2-2.5 $\mu \mathrm{m}$.

Chemistry. Psoromic acid detected by TLC; due to the thinness of the thallus, the characteristic $\mathrm{P}+$ yellow spot test is unreliable.

Etymology. The specific epithet refers to the corticolous habitat ecology of the new species, unusual in a genus that comprises mostly foliicolous taxa.

Distribution and ecology. Mazosia corticola is known from four widely separated localities, three in Tasmania (all from different bioregions of the island) and one from Victoria. All are from the bark of the subdominant, cool temperate rainforest tree, Atherosperma moschatum, a tree with a persistently smooth, aromatic bark. Within rainforest vegetation, Atherosperma is known for supporting

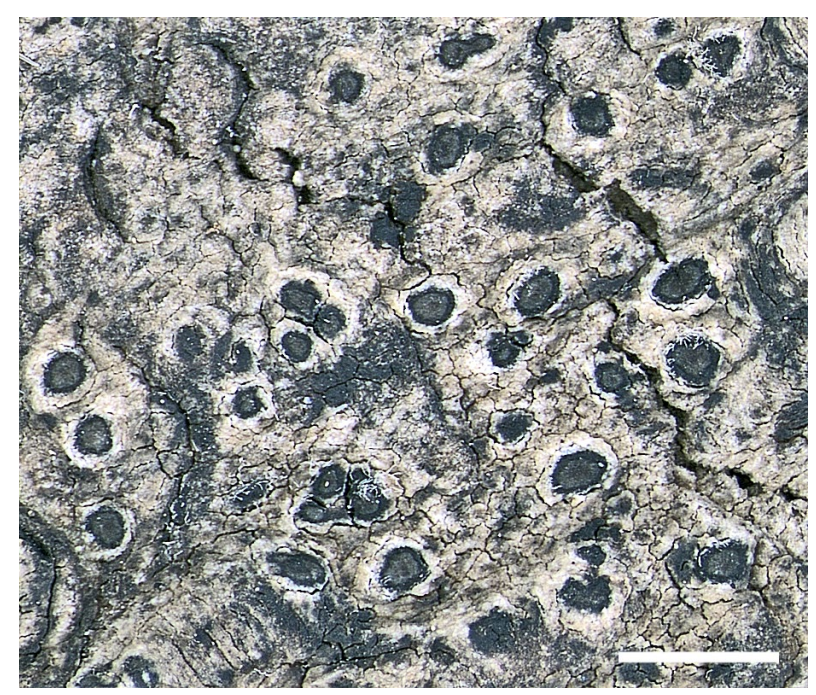

Figure 1. Mazosia corticola habit (holotype). Scale $=1 \mathrm{~mm}$. a distinctive suite of lichens. For example, there are the recently described Coenogonium atherospermatis and Megalaria planocarpa, and many crustose species from genera such as Pyrenula and Graphis which are confined to this host tree or almost so. The leaves of Atherosperma are also one of the principal hosts for the small number of foliicolous lichens that are found in Tasmanian cool temperate rainforest (McCarthy et al. 2001).

Taxa associated with the new species, as gleaned mainly from an examination of herbarium specimens, include: Bactrospora homalotropa, Byssoloma subdiscordans, Graphis librata, Megalaria planocarpa, Phlyctis subuncinata, Porina constrictospora, P. sylvatica, Psoromaria rosulata, Pyrenula dermatodes, Thelotrema lepadinum and T. suecicum.

Notes. Remarkable as the habitat ecology of the new species is, there is no doubt that it belongs in Mazosia. It compared favourably with herbarium material of the generitype, M. rotula, M. phyllosema, the other taxon of the genus known to occur in the region, and several other species of Mazosia available for study, and with published accounts, notably those of Lücking (2008), Aptroot et al. (2014) and Sakata et al. (2017). Critical characters of the new species are the Trentepohlia photobiont, characteristic for corticolous taxa, as distinct from foliicolous taxa that contain Phycopeltis (Aptroot et al. 2014), the stratified construction of the apothecial margin, notably the layer of pigmented excipular hyphae overlain by a layer of crystals that is in turn overlain by a thalline layer (Lücking 2008), the particular ascus type (Fig. 2), the branched and anastomosing paraphyses, and the distinctive ascospores with an enlarged, uppermost median cell (Aptroot et al. 2014; Lücking 2008, Fig. 2). The presence of psoromic acid is also consistent with Mazosia, with several foliicolous species containing this substance.

Within the genus in general, M. corticola is closest to M. phyllosema with respect to ascospore size and gross morphology, but that species is foliicolous, contains Phycopeltis, and lacks secondary compounds. The corticolous species of Mazosia were comprehensively revised by Aptroot et al. (2014) and an expanded key to all species was published by Sakata et al. (2017), enabling ready comparisons with $M$. corticola. None of the taxa treated contain psoromic acid. Furthermore, the ascospores of M. carnea, M. endonigra, M. japonica and M. viridescens (syn. M. ocellata) are all smaller (collectively 15-20 $\times 3-6 \mu \mathrm{m})$, whereas those of $M$. leptosticta are larger $(22-35 \times 4-7 \mu \mathrm{m})($ Aptroot et al. 2014; Sakata et al. 2017). Although the ascospores of $M$. bruguierae and M. corticola are of similar size, the former differs by having prominently elevated, rather than sunken, semi-immersed apothecia. Such apothecia are found not only in the new species, but also in M. leptosticta (larger spores) and $M$. japonica (smaller spores). On these characters alone, the new species stands as clearly distinct.

Additional specimens examined. AUSTRALIA. Tasmania, Little Fisher River, $41^{\circ} 45^{\prime} \mathrm{S} 146^{\circ} 20^{\prime} \mathrm{E}, 820$ m, 17 Aug. 1982, G. Kantvilas s.n. (HO); Anthony Road, $41^{\circ} 50^{\prime} \mathrm{S} 145^{\circ} 38^{\prime} \mathrm{E}$, 600 m, 10 May 1991, G. Kantvilas 250/91 (HO). VICTORIA. 

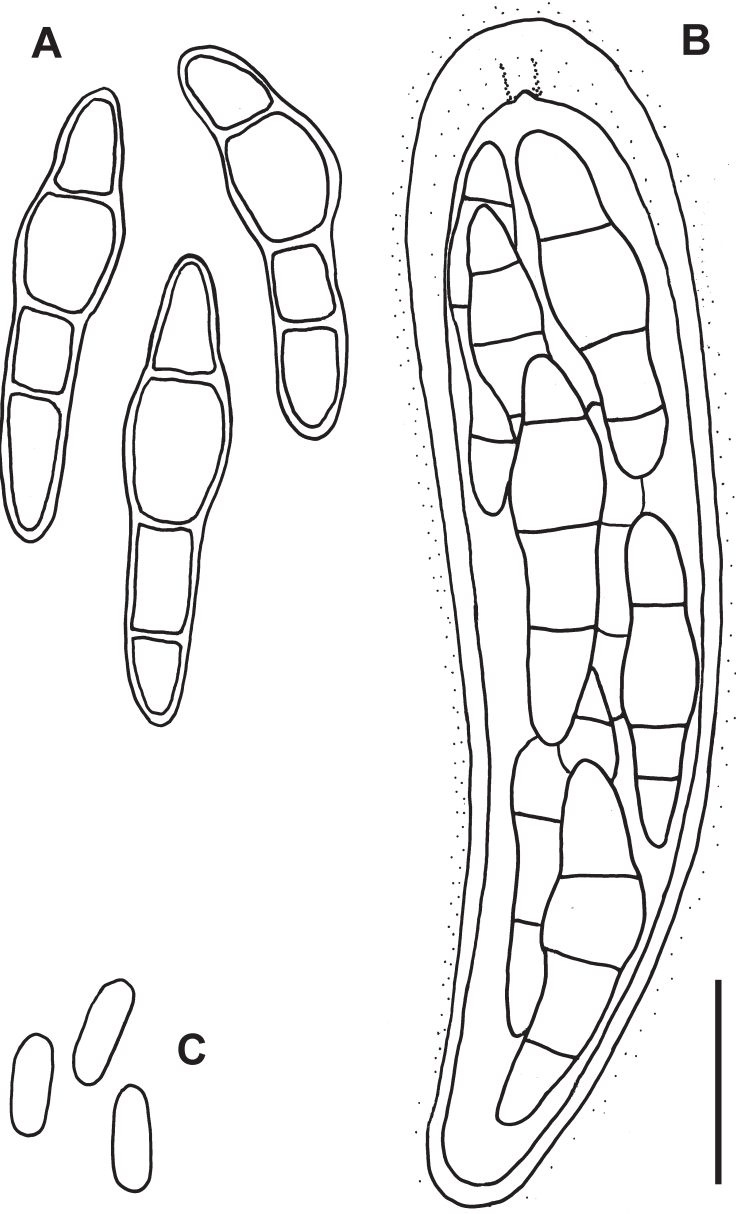

Figure 2. Mazosia corticola anatomy. A - ascospores; B - ascus and ascospores with $\mathrm{KI}+$ blue tissues stippled; $\mathrm{C}-$ conidia. Scale $=10 \mu \mathrm{m}$.

Cement Creek $37^{\circ} 42^{\prime} \mathrm{S} 145^{\circ} 44^{\prime} \mathrm{E}, 23$ Oct. 1993, G. Kantvilas 110/93, P.M. McCarthy \& S. Louwhoff (HO).

Comparative material also examined.-Mazosia melanophthalma (Müll. Arg.) R. Sant. AUSTRALIA. Queensland, D'Aguillar Range, $2 \mathrm{~km} \mathrm{~N}$ of Mt Glorious, 1986, J. Hafellner \& R. Rogers (A. Vězda: Lichenes Selecti Exsiccati 2198) (HO)._Mazosia phyllosema (Nyl.) Zahlbr. AUSTRALIA. Queensland, slopes of Black Mountain, 16²40'S 145²9'E, 1984, H. Streimann 31107B (CANB).- Mazosia pilosa Kalb \& Vězda. BRAZIL. Amazonas, Manaus, Rio Negro, 1980, K. Kalb (A. Vězda: Lichenes Selecti Exsiccati 2227) (HO).-Mazosia pseudobambusae Kalb \& Vězda. BRAZIL. São Paulo, Ilha de São Sebastio, 1980, K. Kalb, J. Poelt \& H. Sipman (A. Vězda: Lichenes Selecti Exsiccati 2228) (HO)._Mazosia rotula (Mont.) A. Massal. BRAZIL. São Paulo, between Osasco and Cabreúva, 1979, K. Kalb 169 (HO).

Mazosia phyllosema (Nyl.) Zahlbr., Cat. Lich. Univers. 2: 503. 1923.

$\equiv$ Platygrapha phyllosema Nyl., Bull. Soc. Linn. Normandie, Ser. 2, 7: 171. 1873.

Mazosia phyllosema is characterised by a foliicolous habit, a Phycopeltis photobiont, rounded, immersed to adnate apothecia, $0.3-0.6 \mathrm{~mm}$ wide with a grey to black, plane disc, and fusiform, 3-septate ascospores, 15-26 $\times$ 4-5 $\mu \mathrm{m}$ [see Santesson (1952) and Lücking (2008) for comprehensive descriptions]. Tasmania appears to be at the ecological limits for this pantropical species. All collections comprise scattered, circular, grey-brown thalli, 1-2.5 $\mu \mathrm{m}$ wide, lacking a prothallus, with the Phycopeltis photobiont cells rectangular, oblong or rhomboidal, 12-20 $\times 6-12 \mu \mathrm{m}$ and arranged in radiating plates. Apothecia are rare and immature, although they display the structure and asci characteristic of the genus. Conical, perithecia-like, emergent pycnidia are abundant with oblong macroconidia, 5-6.5 × $2 \mu \mathrm{m}$. These Tasmanian specimens are too scant for chemical analyses, although Lücking (2008) reports that this species contains no secondary substances.

Habitat and distribution. This species was first recorded for Tasmania by McCarthy et al. (2001). It occurs on the leaves of Atherosperma moschatum and the fronds of the fern Blechnum wattsii in the shaded understorey of rainforest. Associated species include Arthonia trilocularis, Byssoloma subundulatum, Fellhanera endopurpurea, Porina subapplanata and Trichothelium assurgens. Nowhere is it common.

Specimens examined. AUSTRALIA. Tasmania: Bun Hill, ForestIer Peninsula, 42 $58^{\prime} \mathrm{S} 147^{\circ} 56^{\prime} \mathrm{E}, 320$ m, 12 July 1997 , G. Kantvilas s.n. (HO); track to Mt Mueller, $42^{\circ} 48^{\prime} \mathrm{S} 146^{\circ} 31^{\prime} \mathrm{E}$, 640 m, 21 Feb. 1998, G. Kantvilas 6/98 (HO); Bermuda Road, Scotts Divide, $43^{\circ} 05^{\prime} \mathrm{S} 146^{\circ} 53^{\prime} \mathrm{E}, 460$ m, 9 Feb. 1999, G. Kantvilas 49/99A (HO).

\section{Acknowledgement}

I thank Jean Jarman for the photograph and for preparing all figures for publication, and two anonymous referees for helpful suggestions.

\section{References}

Aptroot, A., Menezes, A.A, Xavier-Leite, A. B., dos Santos, V. M., Alves, M. M. E. \& Cáceres, M. E. S. 2014. Revision of the corticolous Mazosia species, with a key to Mazosia species with 3-septate ascospores. The Lichenologist 46: 563-572.

Elix, J. A., Giralt, M. \& Wardlaw, J. H. 2003. New chloro-depsides from the lichen Dimelaena radiata. Bibliotheca Lichenologica 86: 1-7.

Ertz, D., Tehler, A., Irestedt, M., Frisch, A., Thor, G. \& van den Boom, P. 2015. A large-scale phylogenetic revision of Roccellaceae (Arthoniales) reveals eight new genera. Fungal Diversity 70: 31-53.

Kalb, K. \& Vězda, A. 1988. Die Flechtengattung Mazosia in der Neotropis (eine taxonomisch-phytogeographische Studie). Folia Geobotanica et Phytotaxonomica, Praha 23: 199-210.

Lücking, R. 2008. Foliicolous lichenized fungi. Flora Neotropica 103: $1-866$.

Lücking, R. \& Matzer, M. 1996. Ergänzungen und Verbesserungen zur Kenntnis der foliikolen Flechtenflora der Costa Ricas. De Familie Opegraphaceae (einschisslichder Gattung Mazosia). Nova Hedwigia 63: 109-144.

Massalongo, A. 1854. Neagenea Lichenum. Verona.

McCarthy, P. M. 2020. Checklist of the Lichens of Australia and its Island Territories. Australian Biological Resources Study, Canberra. Version 1 March 2020. http://www.anbg.gov.au/abrs/lichenlist/introduction.html

McCarthy, P. M., Kantvilas, G. \& Vězda, A. 2001. Foliicolous lichens in Tasmania. Australasian Lichenology 48: 16-26.

Orange, A., James, P. W. \& White, F. J. 2010. Microchemical Methods for the Identification of Lichens. $2^{\text {nd }}$ edition. British Lichen Society, London. 
Sakata, A., Harada, H. \& Yoshikawa, H. 2017. Taxonomic study on the lichen family Roccellaceae (Arthoniales) of Japan (5). Two new corticolous species of Mazosia. Lichenology 16: 31-47.

Santesson, R. 1952. Foliicolous lichens I. A revision of the taxonomy of the obligately foliicolous, lichenized fungi. Symbolae Botanicae Upsalienses 12: 1-590.
Sparrius, L. B. 2004. A monograph of Enterographa and Sclerophyton. Bibliotheca Lichenologica 89: 1-141.

Torrente, P. \& Egea, J. M. 1989. La familia Opegraphaceae en el área Mediterránea de la Peninsula Ibérica y Norte de África. Bibliotheca Lichenologica 32: 1-282. 